\title{
Analysis of Emotional Intelligence, Environment and Discipline on Student Learning Achievement
}

\author{
Yunita, Indasah, Siti Farida \\ SMK Visi Global, Banyuwangi, \\ Indonesia \\ Email: \\ yunitaningrahayu54@gmail.com
}

Received: March 12, 2019

Accepted : October 13, 2019

Published : November 26, 2019

\begin{abstract}
Education is very important for improving the quality of human resources. Associated with the world of education, to create high quality and high achievers. Factors that can influence learning include emotional intelligence, the environment and the discipline in which individuals carry out certain activities so that they can achieve maximum performance. The purpose of the study was to analyze the effect of emotional intelligence, environment and discipline on student achievement in Health Vocational School Visi Global in Banyuwangi Regency . In this study, the research design used was cross sectional. The study population was all students of Banyuwangi Health Vocational School Visi Global 117 students and a sample of 91 people using stratified random sampling . Collecting data using a questionnaire sheet and then analyzed using multiple linear regression test. The results showed that a significant probability of $\mathrm{F}$ value of $0.000<0.05$ means that there is an influence of emotional intelligence (X1), learning environment (X2) and learning discipline (X3) simultaneously or partially have a significant effect on learning achievement (Y) in Vocational School in Visi Global Banyuwangi Regency. Based on the results of this study, it needs to be at the level of things that affect learning achievement by providing facilities and infrastructure that support learning that is not yet available and create a more comfortable learning environment..
\end{abstract}

Keywords: Emotional Intelligence, Environment, Discipline, Learning Achievement 


\section{INTRODUCTION}

Education is a necessity throughout life ( long life education ). Education is very important for improving the quality of human resources, thus education must be directed to produce quality people who are able to compete in the era of globalization and have a noble character. One of the goals of education is to prepare students to become members of the community who have academic and professional abilities that can apply, develop and create science, art and technology (Rahman, 2017).

Associated with the world of education, to create quality and high-achieving people, students must have good learning achievements. Factors that can influence learning include motivation, environment and discipline in which individuals carry out certain activities. Individuals who live in a community will certainly be influenced by the living environment so that the good and bad learning achievements are influenced by the surrounding environment (Ernawati, 2014).

Emotional intelligence is one factor that determines the effectiveness of learning. Students will study seriously if they have good emotional intelligence. According to Goleman (2015), emotional intelligence is an emotional skill which includes the ability to control oneself and have resistance when facing obstacles, able to control impulses and not feel satisfied quickly, able to regulate mood and be able to manage anxiety so as not to interfere with thinking ability, able empathize and hope. Emotional intelligence will develop creativity and imagination first, so when students learn mathematics will show far better results.

The learning environment is one part of the learning process to achieve learning goals, where the environment will affect teaching and learning activities in schools. The condition of a comfortable classroom will help students to concentrate more easily, get maximum learning outcomes and can enjoy learning activities well (Samodra, 2013).

Learning discipline is a very important condition and determines the success of a student in the learning process. Discipline is the central point in education, without discipline there will be no agreement between teachers and students which results in less than optimal achievement, especially learning. According to Arikunto (2010), discipline is a person's obedience in following rules or rules because it is driven by the existence of awareness in his heart.

The results of a preliminary study at Visi Global Health Vocational School obtained information that at this school had implemented a planned and systematic guidance and counseling program. In fact the school does not yet have data regarding the effects of providing a learning environment and learning discipline. This effect recognition is expected to help schools and teachers in determining attitudes in teaching that are in accordance with the environment and learning discipline. While the achievement motivation possessed by students is also quite good in this case it can be indicated by students' academic learning achievement which can be seen from the results of their graduation $100 \%$ of students graduate with graduation standards in each field of study.

Starting from the description above, the researcher is interested in examining the influence of emotional intelligence, environment and discipline on student achievement in Health Vision Global Banyuwangi District Vocational School.

\section{MATERIALS AND METHODS}

The design used in this study is cross-sectional. The population is all students Health Vision Visi Global Banyuwangi 117 female students The sample size is 91 The respondent uses the STRAT ified random sampling technique. Independent research variables are emotional intelligence, environment and discipline. The dependent variable is the learning achievement. Data were collected using a questionnaire, then the data were analyzed using multiple linear regression tests with a significance level of $\leq 0.05$. 
RESULT

Table 1 Frequency distribution based on emotional intelligence

\begin{tabular}{ccc}
\hline Emotional Intelligence & $\mathrm{n}$ & $\mathrm{f}(\%)$ \\
\hline High & 71 & 78,0 \\
\hline Medium & 20 & 22,0 \\
\hline Low & - & - \\
\hline Total & 91 & 100
\end{tabular}

Based on Table 1 shows that out of 91 respondents most have high category emotional intelligence, namely 71 respondents $(78,0 \%)$.

Table 2 Frequency distribution based on the learning environment

\begin{tabular}{ccc}
\hline Learning Environment & $\mathrm{n}$ & $\mathrm{f}(\%)$ \\
\hline Well & 85 & 93.4 \\
\hline Enough & 6 & 6.6 \\
\hline Less & - & - \\
\hline Total & 91 & 100 \\
\hline
\end{tabular}

Based on Table 2 shows that from 91 respondents almost all have a Learning Environment in the good category, as many as 85 respondents $(93.4 \%)$.

Table 3. Distribution of respondents based on learning discipline

\begin{tabular}{ccc}
\hline Learning Discipline & $\mathrm{n}$ & $\mathrm{f}(\%)$ \\
\hline High & 81 & 89.0 \\
\hline Medium & 10 & 11.0 \\
\hline Low & - & - \\
\hline Total & 91 & 100 \\
\hline
\end{tabular}

Based on table 3 shows that out of 91 respondents almost all had good Learning Discipline in the category of 85 respondents $(93.4 \%)$.

Table 4. Distribution of respondents based on learning achievement

\begin{tabular}{ccc}
\hline Learning achievement & $\mathrm{n}$ & $\mathrm{f}(\%)$ \\
\hline Well & 24 & 26,4 \\
\hline Enough & 62 & 68,1 \\
\hline Less & 5 & 5.5 \\
\hline Total & 91 & 100 \\
\hline
\end{tabular}

Based on Table 4 shows that from 91 respondents almost all have good category learning achievement that is 86 respondents $(94.5 \%)$.

Table 5. Test results for normality

One-Sample Kolmogorov-Smirnov Test

\begin{tabular}{llrrrr}
\hline & & $\begin{array}{c}\text { Emotional } \\
\text { Intelligence }\end{array}$ & $\begin{array}{c}\text { Learning } \\
\text { Environment }\end{array}$ & $\begin{array}{c}\text { Learning } \\
\text { Discipline }\end{array}$ & $\begin{array}{c}\text { Learning } \\
\text { achievement }\end{array}$ \\
\hline $\mathrm{N}$ & & 91 & 91 & 91 & 91 \\
\hline \multirow{2}{*}{ Normal Parameters a, b $^{\mathrm{a}}$} & Mean & 59,6703 & 64,7143 & 64,1319 & 83,0682 \\
\cline { 2 - 6 } & Std. Deviation & 3,40606 & 4,49762 & 5,22432 & 6,83585 \\
\hline \multirow{2}{*}{$\begin{array}{l}\text { Most Extreme } \\
\text { Differences }\end{array}$} & Absolute &, 137 &, 130 &, 111 &, 120 \\
\cline { 2 - 6 } & Positive &, 137 &, 073 &, 093 &, 120 \\
\cline { 2 - 6 } & Negative &,- 132 &,- 130 & -111 & -112 \\
\hline Kolmogorov-Smirnov Z & & 1,308 & 1,241 & 1,060 & 1,141 \\
\hline Asymp. Sig. (2-tailed) & &, 065 &, 092 &, 211 &, 148 \\
\hline
\end{tabular}


a. Distribution test is Normal.

b. Calculated from data.

Based on the results / output above, the value of probalilitas to four variables are emotional intelligence, learning environment, learning discipline and learning achievement of significant values $>0.05$ means that the data is normally distributed.

Table 6. Multiple linear regression

\section{Coefficients $^{\text {a }}$}

\begin{tabular}{|c|c|c|c|c|c|c|c|c|}
\hline \multirow[t]{2}{*}{ Mode } & & \multicolumn{2}{|c|}{$\begin{array}{c}\text { Unstandardized } \\
\text { Coefficients }\end{array}$} & \multirow{2}{*}{$\begin{array}{c}\text { Standardized } \\
\text { Coefficients }\end{array}$} & \multirow[t]{2}{*}{$t$} & \multirow[t]{2}{*}{ Sig. } & \multicolumn{2}{|c|}{$\begin{array}{l}\text { Collinearity } \\
\text { Statistics }\end{array}$} \\
\hline & & $\mathrm{B}$ & Std. Error & & & & Tolerance & VIF \\
\hline \multirow{4}{*}{1} & (Constant) & $-30,220$ & 12,229 & & $-2,471$ &, 015 & & \\
\hline & $\begin{array}{l}\text { Emotional } \\
\text { intelligence }\end{array}$ & , 644 &, 151 & , 321 & 4,272 & , 000 & , 975 & 1,026 \\
\hline & $\begin{array}{l}\text { Learning } \\
\text { environment }\end{array}$ &, 543 & , 113 &, 358 & 4,819 &, 000 & , 998 & 1,002 \\
\hline & $\begin{array}{l}\text { Learning } \\
\text { discipline }\end{array}$ & , 619 & , 098 & , 473 & 6,303 &, 000 & , 975 & 1,026 \\
\hline
\end{tabular}

a. Dependent Variable: learning achievement

Sumber: Attachment 6 is processed.

The dependent variable in this multiple linear regression model is learning achievement (Y) while the independent variables are emotional intelligence $\left(\mathrm{X}_{1}\right)$, learning environment $\left(\mathrm{X}_{2}\right)$ and learning discipline $\left(\mathrm{X}_{3}\right)$.

The regression model based on the results of the analysis above is

$$
\hat{\mathrm{Y}}=-30,220+0.644\left(\mathrm{X}_{1}\right)+0.543\left(\mathrm{X}_{2}\right)+0.619\left(\mathrm{X}_{3}\right)
$$

The interpretation of the above equation is:

a. $\beta_{0}=-30,220$

In the model $-30,220$ is the intersection between the regression line with the $\mathrm{Y}$ axis (intercept).

b. $\quad \beta_{1}=0.644$

Parameter value or regression coefficient for emotional intelligence variable $\left(\mathrm{X}_{1}\right)$ is positive at 0.644 , meaning that the higher the emotional intelligence, the higher learning achievement (Y) or vice versa.

c. $\quad \beta_{2}=0.543$

The parameter value or regression coefficient for the learning environment variable $\left(\mathrm{X}_{2}\right)$ has a positive value of 0.543 which means that it is better the learning environment is higher learning achievement (Y) or vice versa.

d. $\quad \beta_{3}=0.619$

Parameter values or regression coefficients for learning discipline variables $\left(\mathrm{X}_{3}\right)$ have a positive value of 0.619 meaning the higher the discipline of learning the higher learning achievement (Y) or vice versa.

Table 7 Test Results F

ANOVA ${ }^{\text {a }}$

\begin{tabular}{llccccc}
\hline \multicolumn{1}{c}{ Model } & Sum of Squares & df & Mean Square & F & Sig. \\
\hline \multirow{2}{*}{1} & 2195,328 & 3 & 731,776 & 31,670 &, $000^{\mathrm{b}}$ \\
\cline { 2 - 7 } & Regression & 2010,164 & 87 & 23,106 & & \\
\cline { 2 - 7 } & Residual & 4205,592 & 90 & & & \\
\hline
\end{tabular}


a. Dependent Variable: learning achievement

b. Predictors: (Constant), Learning discipline, learning environment, emotional intelligence

Based on the results of statistical decisions, if significance $<\alpha(0,000<0,05)$ then Ho is rejected means emotional intelligence $\left(\mathrm{X}_{1}\right)$, learning environment $\left(\mathrm{X}_{2}\right)$ and learning discipline $\left(\mathrm{X}_{3}\right)$ simultaneously significant effect on learning achievement (Y) d i SMK Visi Global Banyuwangi.

Table 8 Test Results t

\section{Coefficients $^{\text {a }}$}

\begin{tabular}{|c|c|c|c|c|c|c|}
\hline & \multirow[t]{2}{*}{ Model } & \multicolumn{2}{|c|}{ Unstandardized Coefficients } & \multirow{2}{*}{$\begin{array}{l}\text { Standardized } \\
\text { Coefficients } \\
\text { Beta }\end{array}$} & \multirow[t]{2}{*}{$\mathrm{t}$} & \multirow[t]{2}{*}{ Sig. } \\
\hline & & B & Std. Error & & & \\
\hline \multirow{4}{*}{1} & (Constant) & $-30,220$ & 12,229 & & $-2,471$ &, 015 \\
\hline & $\begin{array}{c}\text { Emotional } \\
\text { intelligence }\end{array}$ & , 644 &, 151 &, 321 & 4,272 & 000 \\
\hline & $\begin{array}{c}\text { Learning } \\
\text { environment }\end{array}$ &, 543 &, 113 &, 358 & 4,819 & 000 \\
\hline & $\begin{array}{l}\text { Learning } \\
\text { discipline }\end{array}$ &, 619 &, 098 & , 473 & 6,303 & 000 \\
\hline
\end{tabular}

a. Dependent Variable: learning achievement

1) For emotional intelligence variables $\left(X_{1}\right)$ significant value $0,000<0,05$, thus Ho is rejected then emotional intelligence $\left(\mathrm{X}_{1}\right)$ partially affects the learning achievement in the Visi Global Vocational School in Banyuwangi Regency.

2) For the learning environment variable $\left(X_{2}\right)$ significant value $0,000<0,05$, thus Ho is rejected then the learning environment $\left(\mathrm{X}_{2}\right)$ partially affects the learning achievement in the Visi Global Vocational School in Banyuwangi Regency.

3) For disciplinary learning variables $\left(\mathrm{X}_{3}\right)$ significant value $0.00<0.05$, thus Ho is rejected, the discipline of learning $\left(\mathrm{X}_{3}\right)$ partially affects the learning achievement in the Visi Global Vocational School in Banyuwangi Regency.

4) Of the three variables above, the most dominant influence on learning achievement in Banyuwangi Visi Global Vocational School is the discipline learning variable, because it has the highest $t$ count value of 6.303

\section{DISCUSSION}

\section{Effect of emotional intelligence towards student achievement in the SMK Visi Global Banyuwangi Regency}

Based on the results of this study indicate that out of 91 responses with most emotional intelligence in the high category with sufficient category learning achievement as many as 46 respondents $(50.5 \%)$, and the results of t test for emotional intelligence variables (X 1 ) significant value $0.000<0.05$.

While the results of 91 respondents crosstabulasi mostly high emotional intelligence category to the learning achievement enough category (50.5\%), and cross tabulation obtained acyl $\mathrm{h} \mathrm{p}=0.010$ (OR $=)$ which means that there is the influence of emotional intelligence on learning achievements in vocational Visi Global Banyuwangi Regency. Thus Ho is rejected, emotional intelligence (X 1 ) partially influences student achievement in Health Vision Global Banyuwangi District Vocational School.

The results of this study are similar to the results of a previous study conducted by Marhaeni (2016) which examined the relationship of emotional intelligence to mathematics learning achievement of class V students of primary school I cluster in Wates Subdistrict, Kulon Prago Regency. This study shows that the correlation index is 0.269 and the significance value is $0.001<0.05$ with a large contribution of $7.3 \%$. From the results of this study it can be concluded that there is a positive and significant relationship between emotional intelligence on mathematics learning achievement of class V students of Primary School I in Wates Subdistrict. 
According to Goleman (2015), emotional intelligence means the ability to motivate yourself and endure frustration; controlling impulses and not exaggerating pleasure; regulates mood and keeps stress burden from paralyzing thinking ability; empathize and pray. Salovey in Gelomen (2015), explained that the area of emotional intelligence can be seen from five aspects, namely: recognize self emotions, manage emotions, motivate yourself, recognize the emotions of others, build relationships. According to Gelomen (2015), the factors that influence emotional intelligence Emotional intelligence is not determined from birth but can be done through the learning process. There are several factors that affect emotional intelligence, among them are emotional nerve anatomy, family and school environment, adjustment.

The results showed that most emotional intelligence was in the high category with sufficient category learning achievement. This shows that there is a connection between emotional intelligence and learning achievement. In the process of teaching and learning in schools often found students who can achieve learning equivalent to their intellectual abilities. Therefore, emotional intelligence is one of the important factors that students should have. Students who have a better level of emotional intelligence can become more skilled at focusing attention, better in dealing with others, more capable in understanding people. With emotional intelligence also the individual is able to know and respond to feeling well and able to read and face the feelings of others more effectively.

To achieve optimal emotional intelligence, family and school support is needed. Support place the family is the first and primary students get an education, while school is advanced and what factors have been obtained from the child's family. Both are very influential on the emotional children and families that have a greater influence than schools, because in the family the personality of the child can be formed in accordance with the educational pattern of parents in their lives. Therefore, there is a link between intelligence and learning achievement obtained by students.

\section{Environmental influences on student learning achievement in the Vocational School Visi Global in Banyuwangi Regency}

Based on the results of this study shows that of 91 respondents, most of the learning environment was in good category to Enough category learning achievement ( $64.8 \%$ ), and the results of the $t$ test for environmental variables (X2) significant value $0.000 \square 0.05$.

While crosstabulation results from 91 respondents most of the learning environment was in the good category with sufficient learning achievement category (64.8\%), and cross tabulation of test results obtained $\mathrm{p}=0.008(\mathrm{OR}=)$ ) which means that there is environmental influence on student achievement in SMK Global Vision Health Banyuwangi. Thus Ho is rejected, the learning environment (X 2 ) partially affects the learning achievement in the Global Vision Vocational School in Banyuwangi Regency .

According to Wahyuningsih and Djazari (2013), the learning environment is an environment that influences the learning process both physical and social environment. The environment will affect individuals and vice versa, individuals can also affect the environment (Yusuf, 2011). Learning environments such as facilities and infrastructure, environmental area, lighting and noise have a great influence on the assessment of the fun or not of the learning environment so that it can affect motivation and the learning process. The condition of a comfortable classroom will help students to concentrate more easily, get maximum learning outcomes and can enjoy learning activities well (Samodra, 2013).

The results showed no link between the environment learned to study accomplishments. The condition of this learning environment greatly determines the smooth process of learning in school. If the learning environment supports, then students will be more enthusiastic in learning. Because the learning environment can stimulate every stimulus which students have to respond to. Besides that, this learning environment is complementary and supports the development of knowledge abilities owned by students so that learning achievement can be achieved optimally.

The learning environment factors here are two things: internal and external factors, where the first internal factor is intelligence (intelligence) where the high and low intelligence shows the ability in accordance with the level of peer development. Second is physical or psychological factors where when students are unwell, their desire to learn is reduced. The three attitudes, in students must be a positive attitude (accept) to fellow students or to the teacher, a positive attitude will provide enthusiasm for learning. And conversely students who have a negative attitude (reject) to fellow students and their teachers will not have the will to learn. Fourth, interest can be said to occur because of feelings of 
pleasure in something, interest has a large influence on learning. If you use a subject, students will learn happily without burden. Fifth is talent, every person has talent in the sense of having the potential to achieve achievements to a certain level in accordance with their respective abilities. The sixth motivation, strong weak motivation to learn also influences the success of learning, in teaching and learning activities students will succeed if they have the motivation to learn.

The first external factor is the family, where the family environment is the first and foremost place, the sense of security in the family will encourage someone to learn actively because security is one of the external driving factors that increase motivation to learn. The second school environment, a good school environment can encourage students to study harder. The condition of this school includes how to present learning provided by the teacher, the relationship between the teacher and students, the learning tools used by the teacher, as well as the existing facilities and infrastructure in the school environment. A good relationship between teacher and student will affect student learning outcomes.

\section{The influence of learning discipline on student achievement in the Vocational School Visi Global in Banyuwangi Regency}

Based on the results of this study indicate that of the 91 respondents most of the discipline of learning high category of learning achievement in the category enough $(59.3 \%)$, and the results of $t$ test for variables discipline of learning (X 3 ) significant value $0.000<0.05$.

The results of crosstabulation test from 91 respondents most of the discipline in high category learning with sufficient category learning achievement (59.3\%), from the results of cross tabulation obtained $\mathrm{p}=0.024(\mathrm{OR}=)$ which means that there is an influence of learning discipline on learning achievement in vocational schools Health Vision Global Banyuwangi Regency. Thus Ho is rejected, the discipline of learning (X 3) partially the effect against learning achievement at the Global Vision Health District Banyuwangi Vocational School.

The results of this study are similar to the results of research conducted by Aslianda (2017) with the title Learning Discipline Relationships Against Student Learning Outcomes of Class IV SD Negeri 18 Banda Aceh. Based on the results of the study obtained correlation coefficient $(r)=0.59$ where the value explains the existence of a positive and significant influence between the discipline of learning on learning outcomes of fourth grade students of public elementary schools Banda Aceh. From the results of testing the data obtained $r$ count value of 0.59 while $r$ table is 0.361 at the significance level of 5\%. Thus the null hypothesis (Ho) is declared rejected, while the research hypothesis (Ha) is declared acceptable, meaning that there is a positive correlation between the disciplines of learning towards the learning outcomes of fourth grade students of Banda Aceh Elementary School have a sufficient correlation.

According to Slameto (2010) school discipline is closely related to the craft of students in school and also in learning, so that students learn more advanced, students must be disciplined in learning, both at school, at home, and in the library. According to Gunawan (2012), one of the character values developed in school is discipline. Discipline is an action that shows orderly behavior and complies with various rules and regulations.

According to Sulistyowati (2012), there are three school indicators in the character values of discipline, namely the presence of students and teachers, in addition to students who get attendance, teachers also have the presence to discipline the teacher on time when going to school or going home from school. Having rules, having academic rules at each school, so when doing a test or final school exam, you must pay attention to academic rules.

The results of the study show that there is a connection between the discipline of learning and learning achievement. Discipline is an effort to make students to be diligent and active in learning that has been established by both parents and schools. The existence of disciplinary education aims to instill certain patterns of behavior, certain habits, or shape students who people can appreciate time. Thus the existence of self-discipline in learning that is embedded in students, will have an impact on the activeness, perseverance and creativity of students in learning. If the student has time discipline in learning, they will have the motivation or encouragement from within to learn. With the time discipline that has been embedded in them, will bring success and success for students, so that students will be able to show good and satisfying achievements.

To continue to improve students' learning discipline at school, the teacher every day carries out morning pickets for guidance to students, and will provide educational sanctions for students who 
violate, so that with the creation of good school discipline it will encourage students to be more active in learning.

\section{CONCLUSION}

In this study conclusions can be drawn as follows there is an influence of emotional intelligence on learning achievement at achievement at the Vocational School Visi Global in Banyuwangi Regency (significant value $=0.000<0.05$ ). There is an influence of the learning environment on learning achievement at the Vocational School Visi Global in Banyuwangi Regency (significant value $=0.000$ $<0.05$ ) and there is an effect of learning discipline on learning achievement at the Vocational School Visi Global in Banyuwangi Regency (significant value $=0.000<0.05$ ).

\section{REFERENCES}

Arikunto, S. (2010). Manajemen Pengajaran Secara Manusiawi, Jakarta: Rineka Cipta.

Chulsum. (2017). Pengaruh Lingkungan Keluarga, Kedisiplinan Siswa, Dan Motivasi Belajar Terhadap Hasil Belajar Ekonomi Siswa Di SMA Negeri 7 Surabaya. Jurnal Ekonomi Pendidikan dan Kewirausahaan Vol. 5 No. 1 p-ISSN 2303-324X, e-ISSN 2579-387X https://journal.unesa.ac.id/index. php/jepk/article/view/832/629.

Ernawati. (2014). Pengaruh Pola Asuh Orang Tua, Interaksi Teman Sebaya dan Kecerdasan Emosional Terhadap Hasil Belajar IPA Pada Siswa Kelas VIII SMP Negeri Se Kecamatan Mengwi. EJournal Program Pascasarjana Universitas Pendidikan Ganesha Program Studi IPA Volume 4 Tahun 2014.

Goleman, \& Daniel. (2015). Emotional Intelligence: Kecerdasan emosional mengapa EI lebih penting daripada IQ, Jakarta: PT. Gramedia Pustaka Utama.

Samodra, J. (2013). Pendidikan Karakter Melalui Pendidikan Jasmani. Bandung: Bintang Warli Artika.

Rahman, AR, (2012). Pengaruh Motivasi, Lingkungan Dan Disiplin Terhadap Prestasi Belajar Siswa Pada Jurusan Teknik Audio Video SMK Negeri 3 Yogyakarta. http://eprints.uny.ac.id/9495/1/Jurnal.pdf.

Slameto. (2010). Belajar dan Faktor-Faktor yang Mempengaruhinya, Jakarta: Rineka Cipta.

Sulistyowati, \& Endah. (2012). Implementasi Kurikulum Pendidikan Karakter. Yogyakarta: Citra Aji Parama.

Wahyuningsih, \& Djazari. (2013). Pengaruh Lingkungan Sekolah Dan Kebiasaan Belajar Terhadap Prestasi Belajar Akuntansi Siswa Kelas XI IPS SMA Negeri 1 Srandakan. Kajian pendidikan akuntansi Indonesia, 2 (1):137-160.

Yusuf, \& Syamsu. (2011). Psikologi Perkembangan Anak dan Remaja. Bandung: PT. Remaja Rosdakarya 